\title{
PENERAPAN MODEL PEMBELAJARAN GENERATIF UNTUK MENINGKATKAN HASIL BELAJAR IPS SISWA MATERI KONDISI GEOGRAFIS DAN PENDUDUK PADA KELAS VII 2 SMP NEGERI 2 KONAWE
}

\author{
Iskandar Feri Setiawan ${ }^{1}$
}

\section{${ }^{1}$ Alumni Pendidikan Geografi FKIP UHO}

\begin{abstract}
Teacher teaching Activity. 3) Improving learning results. The aims of this research to. 1) Improve the students learning activity ,2) increases teacher teaching activity. 3) Knowing the increase in the results of the study. This study is An action classroom Research, which has been implemented in 2 cycle. The subject of this research the students are registered on the even- in academic year of 2016/2017, numbered 20 students. The date of this research is the activity of teacing process of teacher and learning activities of the students which obtained from the observation sheet and the results of learning as measured through tests. Date analysis was conducted a descriptive statistic. The results showed if. 1) learning activities at each cycle tends to increase. This is demonstrated by average score on each cycle, in cycle I score average is 2.7 students activity increased in cycle II becomes 3.25. 2) on cycle I score an average teacher's teaching activity is increased 2.85 cycle II becomes 3.65. 3) results of study geography enhanced through generative learning model. On cycle I students who finished $13(65 \%)$ and not completely and absolutely no 7 (35\%) with an average of 72.25 whereas at the second cycle was increased to $17(85 \%)$ The students who did not complete 3 students (15\%).
\end{abstract}

\section{Kata kunci: Model Pembelajaran, Proses, Hasil Belajar}

\section{PENDAHULUAN}

Usaha meningkatkan mutu pendidikan merupakan sasaran pokok pembangunan pendidikan. Upaya meningkatkan mutu pendidikan adalah bagian terpadu dari upaya meningkatkan kualitas manusia indonesia, baik dari aspek kemampuan, kepribadian, dan rasa tanggung jawab sebagai warga negara. Salah satu upaya untuk meningkatkan kualitas sumber daya manusia adalah pembelajaran di sekolah. Diantaranya adalah ilmu-ilmu sosial . Ilmu Pengetahuan Sosial (IPS) sebagai salah satu cabang ilmu pengetahuan yang memegang peranan penting dalam pengembangan ilmu pengetahuan dan teknologi. IPS sebagai bagian dari pendidikan merupakan sarana bagi siswa agar mampu berpikir logis dan sistematis, yang telah dirumuskan dalam kurikulum, yaitu sebagai wahana untuk mengembangkan penalaran serta dapat menjelaskan permasalahan dalam kehidupan sehari-hari. Oleh karena itu masalah kualitas pembelajaran IPS memerlukan perhatian yang serius dari pihak-pihak yang terkait khususnya yang melaksanakan proses belajar di dalam kelas.

Guru sangat berperan penting dalam perbaikan proses pengajaran. Guru sepatutnya mampu mencari strategi yang dipandang dapat membelajarkan siswa melalui proses pengajaran yang dilaksanakan agar tujuan pengajaran dapat tercapai secara efektif dan hasil belajar siswa dapat ditingkatkan. Dengan adanya perencanaan yang baik, akan mendukung keberhasilan 
pengajaran. Salah satu upaya untuk meningkatkan sumber daya manusia adalah melalui proses pembelajaran di sekolah. Dalam usaha meningkatkan kualitas sumberdaya pendidikan, guru merupakan sumberdaya manusia yang harus dibina dan dikembangkan.

Usaha meningkatkan kemampuan guru dalam belajar mengajar, perlu pemahaman ulang. Mengajar tidak sekedar mengkomunikasikan pengetahuan agar dapat belajar, tetapi mengajar juga berarti usaha menolong individu pelajar agar mampu memahami konsep-konsep dan dapat menerapkan konsep yang dipahami. Dalam proses pembelajaran, guru perlu menerapkan model pembelajaran yang sesuai dengan karakteristik materi pokok untuk mencapai tujuan pembelajaran.

Berdasarkan fakta dari hasil observasi awal terhadap guru mata pelajaran IPS Kelas $\mathrm{VII}_{2}$ SMP Negeri 2 Konawe pada tanggal 18 Juli 2016 diketahui bahwa model pembelajaran yang diterapkan di Kelas $\mathrm{VII}_{2}$ SMP Negeri 2 Konawe selama ini adalah pengajaran yang masih berpusat pada guru kemudian memberikan soal (penugasan) kepada siswa dengan materi terbatas dan kurangnya fasilitas menjadi kendala bagi guru untuk merancang model pembelajaran yang bervariasi dalam melaksanakan proses belajar mengajar. sehingga membuat siswa cendrung pasif, siswa kurang antusias dalam pelaksanaan belajar mengajar khususnya mata pelajaran IPS sehingga siswa terkesan tidak serius dalam menerima pelajaran, dan guru dalam proses belajar mengajar kebanyakan menggunakan metode ceramah karena dianggap mudah dan gampang untuk diterapkan sehingga siswa tidak terlibat secara aktif pada pelajaran IPS yaitu siswa kebanyakan mendengarkan dan menyalin apa yang disampaikan oleh guru, serta menyebabkan siswa menjadi jenuh dan bosan dengan materi yang diajarkan pada akhirnya berdampak pada hasil belajar. Hal ini mengakibatkan minat atau perhatian dan aktivitas siswa kurang, serta muncul anggapan bahwa pelajaran IPS itu tidak semudah yang dipikirkan. Akibatnya, berpengaruh pada hasil belajar yang bisa ditetapkan di sekolah belum mencapai standar Kriteria Ketuntasan Minimal (KKM), Khususnya untuk materi kondisi geografis dan penduduk tergolong rendah. Hal ini, dapat dilihat dari hasil belajar siswa pada semster genap tahun ajaran 2014/2015 dimana nilai rata-rata hasil ulangan harian siswa ditunjukan dengan rata-rata 60 dari 22 siswa terdapat 11 siswa atau 50\% yang belum mencapai standar KKM yang di tetapkan sekolah , dan pada semester genap tahun ajaran 2015/2016 dimana nilai ratarata hasil ulangan harian siswa ditunjukan dengan rata-rata 65 dari 24 siswa terdapat 14 siswa atau 55\% yang belum mencapai KKM yang ditetapkan oleh sekolah yaitu 70 (tujuh puluh) untuk mata pelajaran IPS. Berdasarkan masalah tersebut peneliti mencoba mencari tahu apa masalah yang di hadapi oleh siswa yang tidak mencapai kriteria ketuntasan minimal (KKM) untuk mata pelajaran IPS. Setelah peneliti mewawancarai beberapa siswa tersebut tentang masalah yang di hadapi sehingga mereka tidak mencapai minimal kriteria ketuntasan minimal untuk mata pelajaran IPS, peneiliti menemukan masaalah yang di hadapi siswa, yaitu guru kurang memberikan pemahaman dasar kepada siswa tentang materi yang akan di ajarkan sehingga siswa merasa bingung dengan materi yang di bawakan oleh guru terlebih pada materi kondisi geografis dan penduduk dan akibatnya siswa menjadi kurang tertarik dan cenderung pasif dengan materi yang di ajarkan . Selain itu guru cenderung menggunakan metode penugasan kepada siswa. Dalam proses pembelajaran yang dilakukan oleh guru khususnya pemberian tugas membuat siswa kurang aktif dalam proses pembelajaran dan bergantung kepada 
teman-temannya untuk mengerjakan tugas terlebih dahulu dan tidak jarang guru menemukan sebagian siswa mengerjakan tugas pada saat jam pelajaran akan dimulai

Atas dasar itulah maka peneliti melakukan penelitian tentang : "Penerapan Model Pembelajaran Generatif Untuk Meningkatkan Hasil Belajar IPS Siswa Pada Materi Kondisi Geografis dan Penduduk Siswa Kelas $\mathrm{VII}_{2}$ SMP Negeri 2 Konawe .

Menurut Hamalik (2008 : 30) belajar merupakan langkah-langkah atau prosedur yang ditempuh untuk mencapai tujuan. Bukti bahwa seseorang telah belajar adalah terjadinya perubahan tingkah laku pada orang tersebut, misalnya dari tidak tahu menjadi tahu, dan dari tidak mengerti menjadi mengerti.

Belajar adalah suatu usaha sadar yang dilakukan oleh individu dalam perubahan tingkah laku baik melalui latihan dan yang menyangkut aspek-aspek kognitif, afektif, dan psikomotorik untuk memperoleh tujuan tertentu(Abdillah dalam Aunurrahman $2010: 35)$.

Syah (2008:89), memberi pengertian bahwa belajar adalah kegiatan yang berproses dan merupakan unsur yang sangat fundamental dalam setiap penyelenggaraan jenis dan jenjang pendidikan. Ini berarti bahwa berhasil atau gagalnya pencapaian tujuan pendidikan itu sangat bergantung pada proses belajar yang dialami siswa, baik ketika ia berada di sekolah maupun di lingkungan rumah atau keluarganya sendiri.

Perpaduan dari kedua unsur manusiawi ini melahirkan interaksi edukatif dengan memanfaatkan bahan ajar sebagai mediumnya.Pada kegiatan belajar mengajar, keduanya (guru dan murid) saling mempengaruhi dan memberi masukan.Karena itulah kegiatan belajar mengajar harus merupakan aktivitas yang hidup, syarat nilai dan senantiasa memiliki tujuan (Fathurrohman, 2007:9).
Menurut Roestiyah (1999:18-19) mengajar bukanlah tugas yang ringan bagi seorang guru. Dalam mengajar guru berhadapan dengan sekelompok murid, mereka adalah mahluk hidup yang memerlukan bimbingan dan pembinaan untuk menuju kedewasaan. Murid setelah mengalami proses pendidikan dan pengajaran diharapkan telah menjadi manusia dewasa yang sadar tanggung jawab terhadap diri sendiri, masyarakat dan kepada Tuhan Yang Esa, manusia yang dapat berwiswasta, berprikebadian, bermoral, dan mandiri.

Winkel (2004:39) mendefinisikan belajar sebagai suatu proses kegiatan mental pada diri seseorang yang berlangsung dalam interaksi aktif individu dengan lingkungannya sehingga menghasilkan perubahan yang relatif menetap/bertahan.

Dari beberapa pendapat para ahli diatas dapat disimpulkan bahwa belajar dan mengajar merupakan dua hal yang tidak bisa dipisahkan satu sama lain, dimana belajar mengarah kepada apa yang harus dilakukan seseorang sebagai penerima pelajaran (siswa), sedangkan mengajar mengarah kepada apa yang dilakukan oleh seorang guru yang menjadi pengajar. Jadi, belajar mengajar merupakan proses interaksi antara guru dan siswa pada saat proses pembelajaran berlangsung dan saling mempengaruhi satu sama lain dalam keberhasilan proses belajar mengajar.

Model pembelajaran generatif dikembangkan pada tahun 1985 oleh Osborne dan Wittrock (Hulukati, 2005). Wittrock (1992) menyatakan bahwa model pembelajaran generatif merupakan suatu model pembelajaran tentang bagaimana seorang siswa membangun pengetahuan dalam pikirannya, seperti membangun ide tentang suatu fenomena atau membangun arti suatu istilah dan jugamembangun strategi untuk sampai pada suatu penjelasan tentang pertanyaan bagaimana dan mengapa. 
Wittrock (Grabowski,2001:720) mengonsepkan model pembelajaran generatif berdasarkan model syaraf dari fungsi otak dan telaah kognitif pada proses pengetahuan. Hal ini ditegaskan Osborne dan Wittrock (Hulukati, 2005) bahwa intisari dari pembelajaran generatif adalah otak tidak menerima informasi dengan pasif, melainkan justru dengan aktif mengkonstruksi suatu interpretasi dari informasi tersebut dan kemudian membuat kesimpulan.Otak bukanlah suatu'blank slate' yang dengan pasif belajar dan mencatat semua informasi yang diberikan.

Sutrisno (Hulukati, 2005) mengemukakan bahwa dari kegiatan belajar yang dilakukan dalam model pembelajaran generatif terlihat bahwa siswa diharapkan dapat mengutarakan konsepnya deng disertai argumentasi, untuk mendukung konsepnya tersebut dan diharapkan siswa dapat beradu pendapat dengan siswa lain. Hal ini diharapkan dapat berpengaruh positif karena siswa akan terbiasa menghargai konsep orang lain dan terbiasa mengutarakan pendapatnya tanpa dibebani rasa ingin menang atau takut kalah.

Grabowski (2001:723) mengatakan bahwa kontribusi penting pada model generatif bagaimanapun juga bergantung pada strategi guru dalam merancang situasi pembelajaran dan mengelola isi materi yang disampaikan agar menarik perhatian siswa.

Sejalan dengan hal tersebut Asmin (2005) mengemukakan bahwa berpikir generatif adalah mencari sebanyak mungkin pemecahan yang sifatnya harus masuk akal, yang bersumber dari fakta yang ditelaah, yang merupakan cara berpikir yang menghasilkanberagam cara dalam menanggapi.

$$
\text { Proses menghubungkan }
$$

(mengkoneksikan) pengetahuan baru dengan pengetahuan yang sudah ada akan melibatkan motivasi. Pengetahuan dari konsepsi awal akan menghasilkan pemaknaan dan pemahaman siswa dalam pembelajaran. Hal ini didukung oleh teori Gagne, yaitu belajar harus didukung oleh peristiwa pembelajaran (instructional event), misalnya memotivasi siswa mengkomunikasikan tujuan pembelajaran, mengarahkan perhatian siswa, membangkitkan transfer (generalisasi), memunculkan kinerja, dan memberikan umpan balik.

Hal ini senada dengan Grobowski (2001:741) mengungkapkan bahwa model pembelajaran generatif member kesempatan kepada siswa untuk aktif mencari informasi dan menemukan konsep pengetahuan yang baru.

Retno sriyawati (2012) telah melakukan penelitian sebelumnya dan menyimpulkan bahwa penerapan model pembelajaran generatif pada hasil belajar geografi siswa kelas XII SMA Negeri 1 Krian Kabupaten Sidoarjo pada materi pokok litosfer mengalami peningkatan sebesar $23,96 \%$. Berdasarkan hal tersebut peneliti memilih model pembelajaran yang diharapkan dapat mengatasi permasalahan yang dihadapi oleh guru, yaitu model pembelajaran generatif siswa dituntut untuk memikirkan masalah yang telah diberikan kemudian mengintegrasikan secara aktif pengetahuan baru dengan menggunakan pengetahuan yang sudah dimiliki sebelumnya Pengetahuan baru itu akan diuji dengan cara menggunakannya dalam menjawab persoalan atau gejala yang terkait. Jika pengetahuan baru itu berhasil menjawab permasalahan yang dihadapi, maka pengetahuan baru itu akan disimpan dalam memori jangka panjang.

Hipotesis tindakan dalam penelitian ini yaitu: 1)dengan menerapkan model pembelajaran generatif dalam pembelajaran IPS maka aktivitas belajar siswa meningkat dengan skor rata-rata, $\geq 3,0,1)$ dengan 
menerapkan model pembelajaran generatif dalam pembelajaran IPS maka aktivitas mengajar guru memperoleh skor dengan rata-rata $\geq 3,0,3$ )dengan menerapkan model pembelajaran generatif dalam pembelajaran IPS maka hasil belajar siswa meningkat dengan skor rata-rata $\geq 70$ sesuai dengan KKM yang ditetapkan sekolah

\section{METODE PENELITIAN}

Penelitian ini dilaksanakan pada semester genap pada tahun ajaran 2016 / 2017 di SMP Negeri 2 Konawe kelas $\mathrm{VII}_{2}$. Sesuai dengan masalah yang diteliti, maka jenis penelitian ini Penelitian Tindakan Kelas (PTK). PTK merupakan suatu kegiatan yang dilakukan oleh guru atau bersama-sama dengan orang lain (kolaborasi) yang bertujuan untuk memperbaiki atau meningkatkan mutu proses pembelajaran dikelas (Iskandar, 2012: 21). Adapun subyek penelitian ini adalah siswa kelas $\mathrm{VII}_{2} \mathrm{SMP}$ Negeri 2 Konawe berjumlah 20 orang terdiri dari laki-laki 9 dan 11 orang perempuan.

Faktor yang diperhatikan dalam penelitian ini adalah : 1)Faktor siswa : faktor yang diperhatikan adalah aktivitas dan hasil belajar siswa dalam memahami konsep tentang materi kondisi geografis dan penduduk, yang di ukur menggunakan kembar observasi aktifitas siswa, 2) Fakor guru : melihat aktivitas guru dalam penerapan model pembelajaran Generatif dalam proses pembelajaran dikelas. Penelitian tindakan kelas ini akan dilaksanakan sebanyak dua siklus dengan tiap siklus dilaksanakan sesuai dengan perubahan yang ingin dicapai pada faktorfaktor yang diteliti. Berdasarkan observasi awal dan diskusi dengan guru bidang studi IPS, ditetapkan bahwa tindakan yang digunakan untuk meningkatkan hasil belajar
IPS khususnya pada materi pokok kondisi geografis dan penduduk adalah memberikan pembelajaran dengan menggunakan model pembelajaran generatif. Penelitian ini menggunakan dua jenis instrumen pengumpulan data yaitu : 1) Tes hasil belajar 2)Lembar observasi. Data dalam penelitian ini dianalisis dengan menggunakan analisis statistik deskriptif . Dimaksudkan untuk memberikan gambaran peningkatan hasil belajar IPS yang diajarkan dengan menggunakan model pembelajaran generatif dengan melalui tes tertulis pada setiap siklus. Indikator keberhasilan dalam penelitian ini terdiri dari indikator keterlaksanaan skenario pembelajaran dan indikator peningkatan hasil belajar siswa. Pelaksanaan tindakan kelas ini dipandang berhasil apabila sudah memenuhi kriteria keberhasilan yaitu : 1 )Segi proses penelitian tindakan kelas ini dikatakan berhasil jika :Rata-rata aktivitas siswa telah memperoleh minimal 3,0, Rata-rata aktivitas guru memperoleh minimal 3,0 2)dari segi hasil minimal $80 \%$ dari siswa secara klasikal memiliki nilai minimal sesuai dengan KKM adalah $\geq 70$.

\section{HASIL PENELITIAN}

Data mengenai aktivitas belajar siswa siklus I kelas $\mathrm{VII}_{2}$ SMP Negeri 2 Konawe selama pelaksanaan pembelajaran dengan menerapkan model pembelajaran Generatif diperoleh dengan menggunakan lembar observasi dengan cara memberikan skor pada setiap aspek aktivitas yang dilakukan oleh siswa sesuai dengan kriteria yang telah ditentukan. Data skor aktivitas belajar siswa dalam kegiatan belajar mengajar pada Siklus I dapat dilihat pada tabel 1 berikut: 
Tabel. 1 Skor Rata-rata Aktivitas Siswa Pada Setiap Siklus 1

\begin{tabular}{|c|c|c|c|c|}
\hline \multirow{2}{*}{ No } & \multirow[b]{2}{*}{ Aktivitas Siswa Yang Dinilai } & \multicolumn{3}{|c|}{ Skor/Siklus I } \\
\hline & & Pert. I & $\begin{array}{c}\text { Pert. } \\
\text { II }\end{array}$ & $\begin{array}{l}\text { Rata- } \\
\text { rata }\end{array}$ \\
\hline 1 & $\begin{array}{l}\text { Siswa Mendengarkan dan memperhatikan } \\
\text { Guru menyampaikan tujuan Pembelajaran }\end{array}$ & 2,7 & 3 & 2,85 \\
\hline 2 & $\begin{array}{l}\text { Siswa mendengarkan/memperhatikan guru } \\
\text { mengenai materi pelajaran yang disampikan }\end{array}$ & 3 & 3,4 & 3,2 \\
\hline 3 & $\begin{array}{l}\text { Siswa mencari kelompok masing-masing yang } \\
\text { telah dibagi oleh guru }\end{array}$ & 2,8 & 3 & 2,9 \\
\hline 4 & $\begin{array}{l}\text { Siswa memperhatikan penjelasan guru } \\
\text { mengenai LKS yang telah dibagikan. }\end{array}$ & 2,5 & 2,9 & 2,7 \\
\hline \multirow[t]{2}{*}{5} & $\begin{array}{l}\text { Siswa berdiskusi dengan kelompoknya dalam } \\
\text { menyelesaikan soal pada LKS }\end{array}$ & 2,2 & 2,8 & 2,5 \\
\hline & & \multicolumn{3}{|c|}{ Skor/Siklus I } \\
\hline No & Aktivitas Belajar Siswa Yang Dinilai & Pert. I & Pert. II & $\begin{array}{l}\text { Rata- } \\
\text { rata }\end{array}$ \\
\hline 6 & $\begin{array}{l}\text { Siswa bekerja sama dengan anggota } \\
\text { kelompoknya dalam menyelesaikan soal pada } \\
\text { LKS }\end{array}$ & 3 & 2,8 & 2,9 \\
\hline 7 & $\begin{array}{l}\text { Siswa bekerjasama dalam menyiapkan laporan } \\
\text { hasil diskusi kelompok }\end{array}$ & 2,6 & 2,6 & 2,6 \\
\hline 8 & $\begin{array}{llll}\text { Siswa Menyimak dan menanggapi hasil } \\
\text { diskusi kelompok lain }\end{array}$ & 2,8 & 2,8 & 2,8 \\
\hline 9 & $\begin{array}{l}\text { Siswa menunjukan antusiasme } / \text { minat } \\
\text { terhadap kegiatan pembelajaran dengan } \\
\text { mengajukan pertanyaan atau umpan balik } \\
\text { Siswa }\end{array}$ & 2,5 & 2,7 & 2,6 \\
\hline 10 & $\begin{array}{l}\text { Menyimak penguatan dan koreksi dari guru } \\
\text { tentang hasil diksusi kelompok }\end{array}$ & 2,3 & 2,9 & 2,6 \\
\hline Rata & rata aktivitas siswa & 2,6 & 2,8 & 2,7 \\
\hline
\end{tabular}

Sub: Data Diolah (2018)

Gambaran rata-rata aktivitas untuk setiap satuan aktivitas belajar yang belajar siswa dengan menerapkan model pembelajaran Generatif pada siklus I dinilai dapat dilihat pada Gambar 1 berikut: 


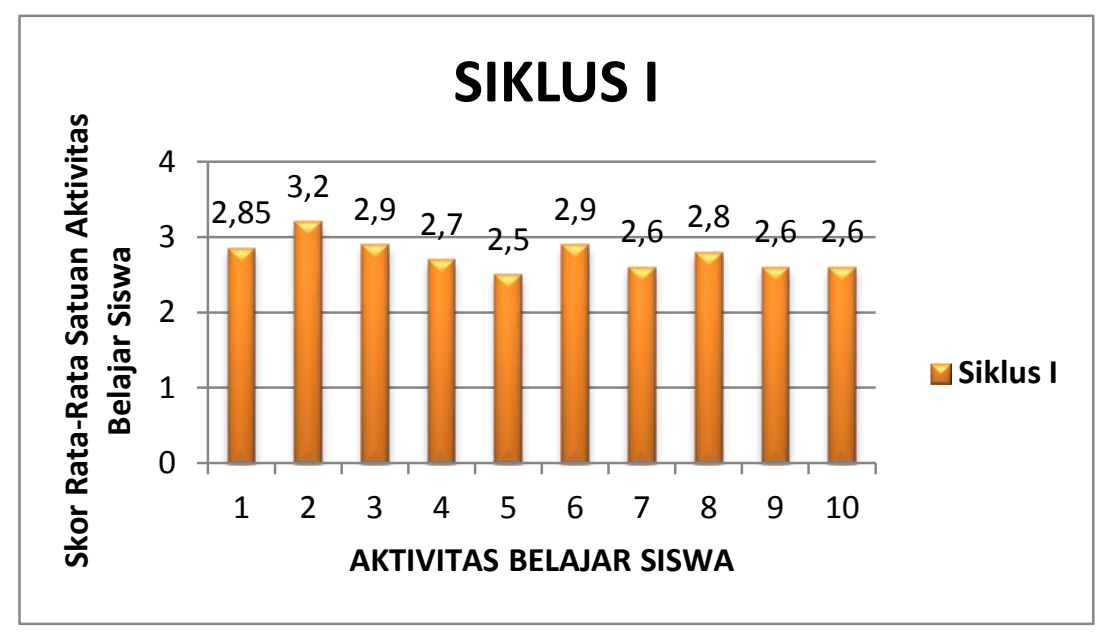

Gambar 4.1. Grafik Skor Rata-rata Satuan Aktivitas Belajar Siswa Siklus 1

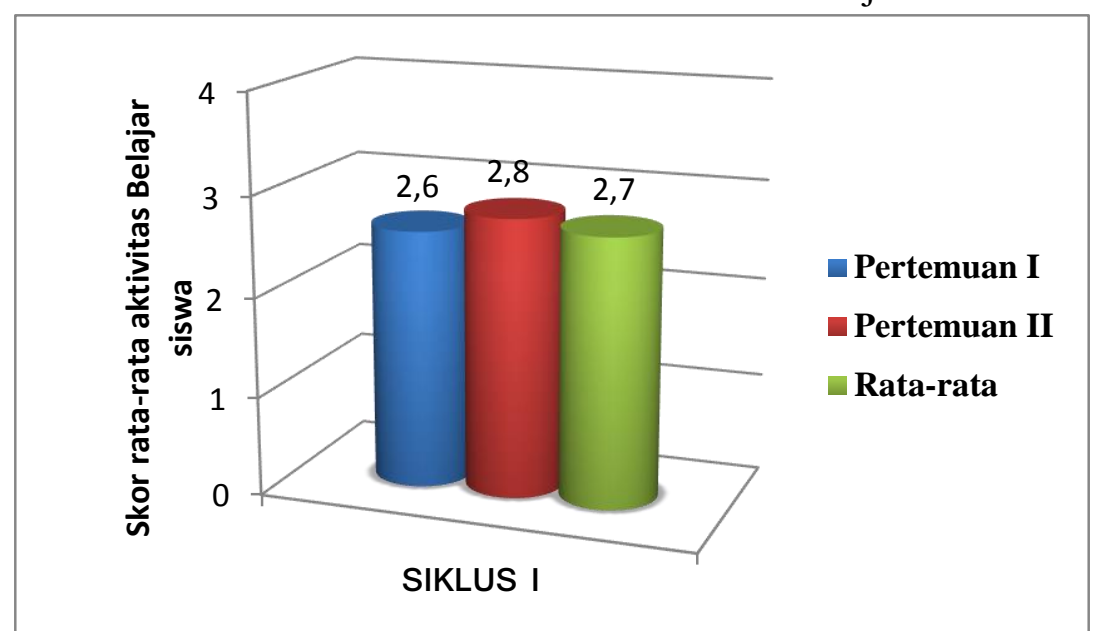

Gambar 4.2 Grafik Skor Rata-rata Aktivitas Belajar Siswa Siklus I

Data Aktivitas Guru Siklus I

Data aktivitas guru dalam mengelola pembelajaran dengan menggunakan model Pembelajaran generatif diperoleh dengan menggunakan lembar observasi aktivitas guru pada siklus I dapat dilihat pada tabel 2 berikut :

\begin{tabular}{|c|c|c|c|c|}
\hline \multirow[t]{2}{*}{ No } & \multirow[t]{2}{*}{ Aspek Yang Dinilai } & \multicolumn{3}{|c|}{ Skor/Siklus I } \\
\hline & & Pert. I & Pert. II & Rata-Rata \\
\hline \multirow{6}{*}{1} & A. Kegiatan Pendahuluan & & & \\
\hline & 1. Guru membuka pelajaran & 3 & 4 & 3,5 \\
\hline & memeriksa kesiapan siswa & & & \\
\hline & $\begin{array}{l}\text { 2. Guru menyampaikan indikatodan } \\
\text { tujuan pembelajaran }\end{array}$ & 3 & 3 & 3 \\
\hline & $\begin{array}{l}\text { 3. Guru menyampaikan mengenai model } \\
\text { pembelajaran yang akan diterapkan }\end{array}$ & 3 & 3 & 3 \\
\hline & $\begin{array}{l}\text { 4. Guru memberikan apersepsi tentang } \\
\text { materi yang akan dipelajari }\end{array}$ & 3 & 3 & 3 \\
\hline
\end{tabular}




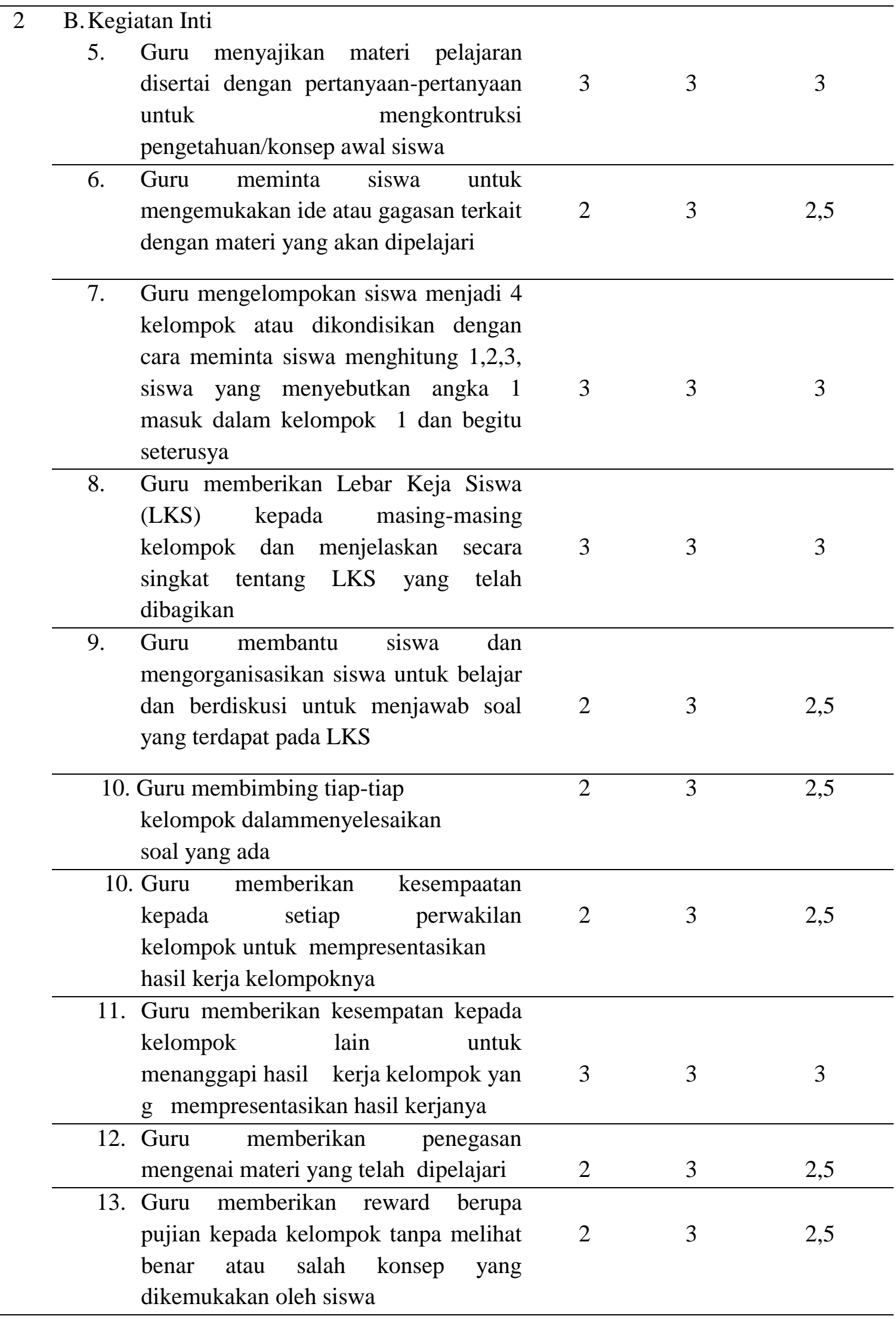


3 C. Kegiatan Akhir

14. Guru memberikan kesempatan kepada siswa untuk bertanya mengenai materi yang kurang dimengerti

\begin{tabular}{lllc}
\hline $\begin{array}{l}\text { 15. Guru bersama sama menyimpulkan } \\
\text { materi yang telah dibahas }\end{array}$ & 2 & 3 & 2,5 \\
\hline $\begin{array}{l}\text { 16. Guru memberikan PR terkait dengan } \\
\text { materi yang diajarkan }\end{array}$ & 3 & 4 & 3,5 \\
\hline 17. Guru menutup proses pembelajaran & 4 & 4 & 4
\end{tabular}

\begin{tabular}{|lccc}
\hline Rata-rata aktivitas guru & 2,6 & 3,1 & 2,85 \\
\hline Kategori & & & Cukup \\
\hline
\end{tabular}

Sub: Data Diolah (2018)

Gambaran rata-rata aktivitas guru dengan menerapkan model pembelajaran generatif yang dinilai dapat dilihat pada Gambar 3 pada siklus I untuk setiap satuan aktivitas berikut :

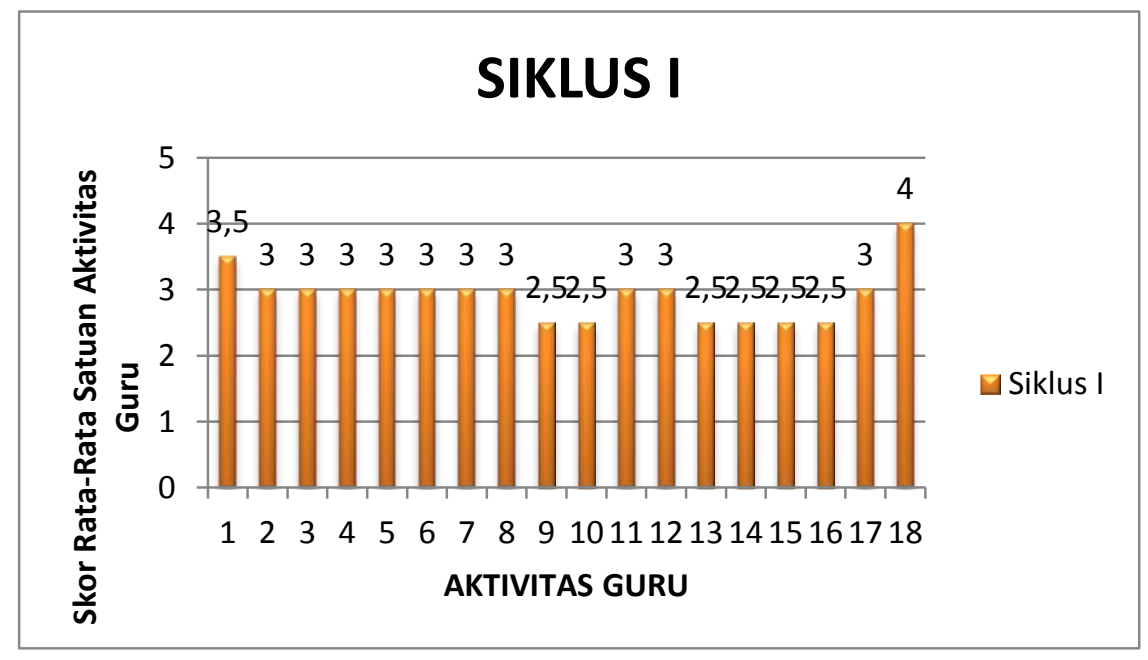

Gambar 4.3 Grafik Skor Rata-rata Satuan Aktivitas Guru Siklus I

Untuk mendapatkan gambaran rata-rata aktivitas guru selama pembelajaran pada siklus I pada pertemuan I dan II dapat dilihat pada Gambar 4 berikut 


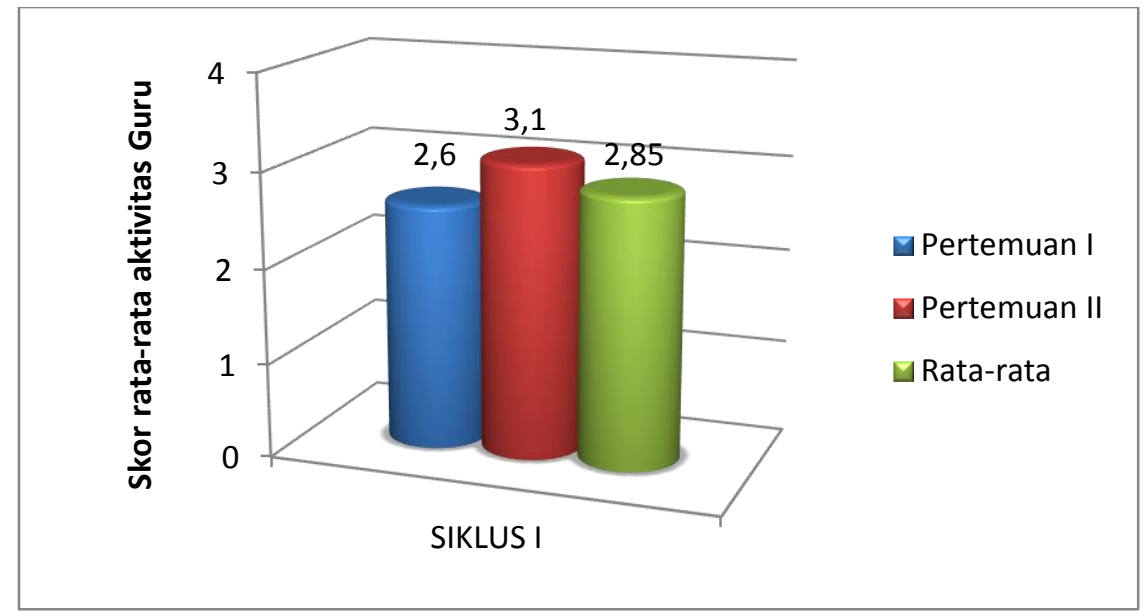

Gambar 4.4 Grafik Skor Rata-rata Aktivitas Guru Siklus I

\section{Data Hasil Belajar Siswa Siklus I}

Data hasil belajar IPS siswa kelas $\mathrm{VII}_{2}$ pada materi Kondisi geografis dan penduduk diperoleh dengan menggunakan lembar tes hasil belajar berupa soal uraian yang diberikan pada akhir siklus. Berdasarkan hasil analisis deskriptif terhadap hasil belajar siswa pada siklus I tersebut, diperoleh data seperti tertera pada tabel 4 berikut :

Tabel 4. Data Analisis Ketuntasan Hasil Belajar Siswa Siklus I

\begin{tabular}{lccc}
\hline \multicolumn{1}{l}{ Skor } & Jumlah siswa & Presentase & Ketuntasan Belajar \\
\hline $0-69$ & 7 orang & $35 \%$ & Belum Tuntas \\
\hline $70-100$ & 13 orang & $65 \%$ & Sudah Tuntas \\
\hline Jumlah & $\mathbf{2 0}$ orang & $\mathbf{1 0 0 \%}$ & \\
\hline Keterangan $:$ & & \\
\hline Tidak Tuntas & $\mathbf{: 7 ~ o r a n g ~}$ & \\
\hline Tuntas & $\mathbf{: 1 3}$ orang & \\
\hline Nilai Rata-rata & $\mathbf{: 7 2 , 2 5}$ & \\
\hline Nilai Maksimum & $\mathbf{: 8 5}$ & \\
\hline Nilai Minimum & $\mathbf{: 5 0}$ & \\
\hline Presentase Ketuntasan $: \mathbf{6 5} \%$ \\
\hline
\end{tabular}

Sub: Data Diolah (2018)

Untuk lebih jelasnya mengenai gambaran hasil belajar siswa kelas $\mathrm{VII}_{2}$ yang diajar dengan menggunakan model pembelajaran generatif pada siklus I dapat dilihat pada gambar 5 berikut: 


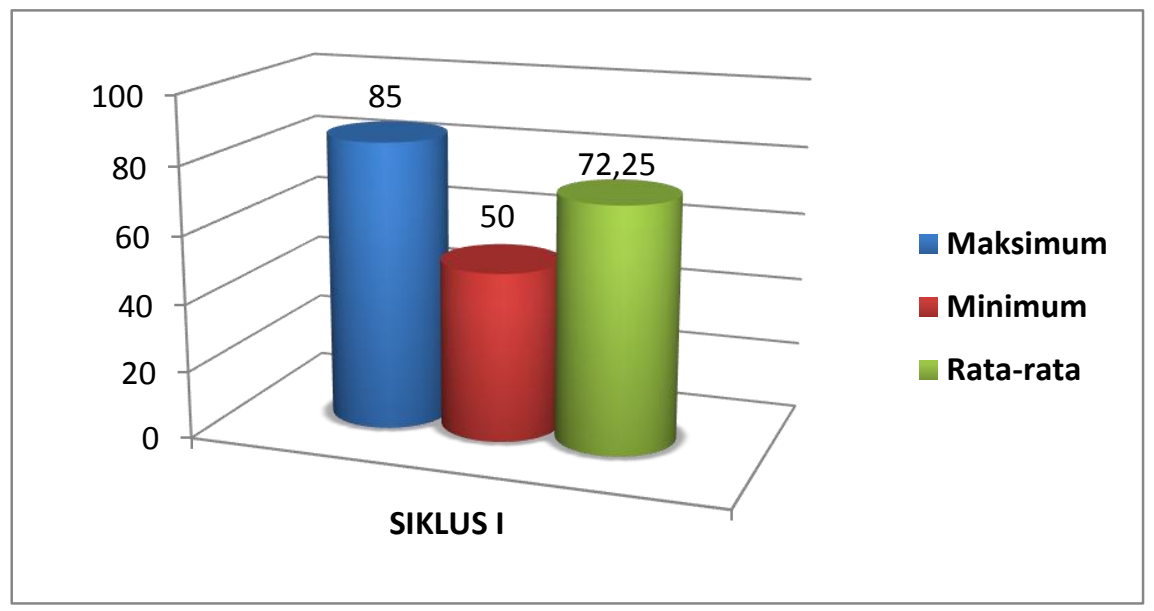

Gambar 5. Grafik Nilai Hasil Belajar Siklus I

Gambar diatas menunjukkan bahwa nilai maksimum yang diperoleh siswa pada esay tes siklus I mencapai 85 dan nilai minimum yang diperoleh siswa pada esay tes siklus I mencapai 50, dengan nilai rata- rata hasil belajar siswa mencapai 72,25 Selanjutnya berdasarkan analisis ketuntasan belajar siswa pada siklus I diperoleh hasil sebagaimana disajikan pada gambar 6 berikut:

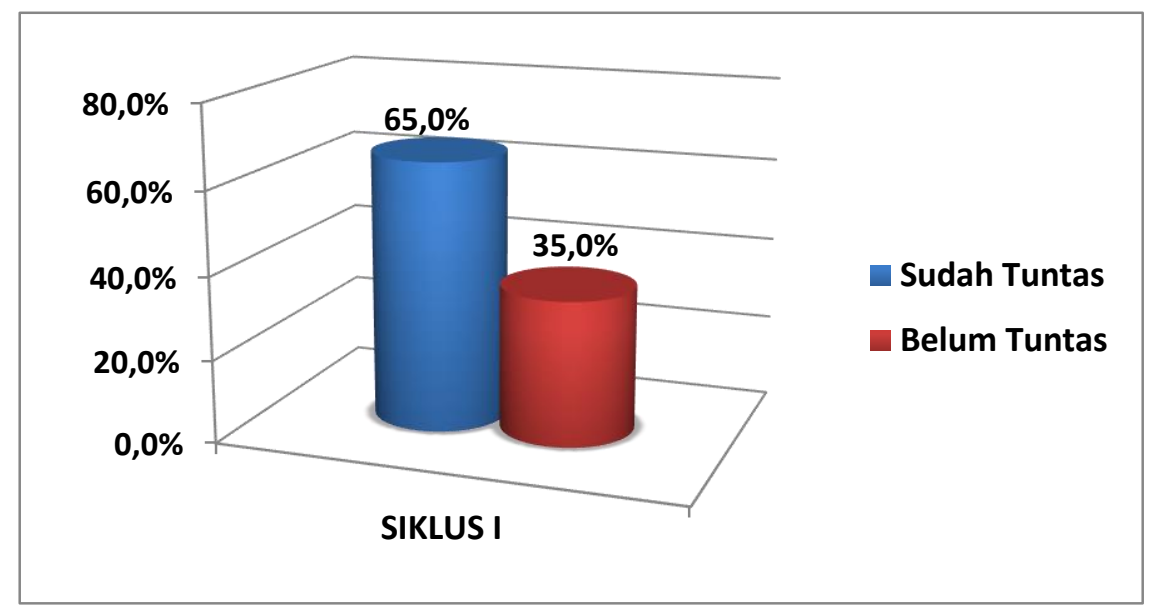

Gambar 4.6. Grafik Presentase Ketuntasan Siswa Siklus I

\section{Hasil Analisis Data Siklus II}

Data mengenai aktivitas belajar siswa kelas $\mathrm{VII}_{2}$ SMP Negeri 2 Konawe selama pelaksanaan pembelajaran dengan menerapkan model pembelajaran generatif diperoleh dengan menggunakan lembar observasi dengan cara memberikan skor pada setiap aspek aktivitas yang dilakukan oleh siswa sesuai dengan kriteria yang telah ditentukan. Data skor aktivitas belajar siswa dalam kegiatan belajar mengajar pada siklus II dapat dilihat pada tabel 6 berikut: 
Tabel 4.5. Skor Rata-rata Aktivitas Belajar Siswa Siklus II

\begin{tabular}{|c|c|c|c|c|}
\hline \multirow[b]{2}{*}{ No } & \multirow[b]{2}{*}{ Aktivitas Belajar Siswa Yang Dinilai } & \multicolumn{3}{|c|}{ Skor/Siklus II } \\
\hline & & Pert. I & Pert. II & Rata-rata \\
\hline \multirow[t]{2}{*}{1} & Siswa Mendengarkan dan memperhatikan & & & \\
\hline & Guru menyampaikan tujuan Pembelajaran & 3,2 & 3,6 & 3,4 \\
\hline 2 & $\begin{array}{l}\text { Siswa mendengarkan/memperhatikan guru } \\
\text { mengenai materi pelajaran yang } \\
\text { disampikan }\end{array}$ & 3,4 & 3,6 & 3,5 \\
\hline 3 & $\begin{array}{l}\text { Siswa mencari kelompok masing-masing } \\
\text { yang telah dibagi oleh guru }\end{array}$ & 3,2 & 3,2 & 3,2 \\
\hline 4 & $\begin{array}{l}\text { Siswa memperhatikan penjelasan guru } \\
\text { mengenai LKS yang telah dibagikan. }\end{array}$ & 3 & 3,2 & 3,1 \\
\hline 5 & $\begin{array}{l}\text { Siswa berdiskusi dengan kelompoknya } \\
\text { dalam menyelesaikan soal pada LKS }\end{array}$ & 2,8 & 3,2 & 3,0 \\
\hline 6 & $\begin{array}{l}\text { Siswa bekerja sama dengan anggota } \\
\text { kelompoknya dalam menyelesaikan soal } \\
\text { pada LKS }\end{array}$ & 3,2 & 3,6 & 3,4 \\
\hline 7 & $\begin{array}{l}\text { Siswa bekerjasama dalam menyiapkan } \\
\text { laporan hasil diskusi kelompok }\end{array}$ & 3,2 & 3,4 & 3,3 \\
\hline 8 & $\begin{array}{l}\text { Siswa Menyimak dan menanggapi hasil } \\
\text { diskusi kelompok lain }\end{array}$ & 3,1 & 3,5 & 3,3 \\
\hline 9 & $\begin{array}{l}\text { Siswa Menyimak penguatan dan koreksi } \\
\text { dari guru tentang hasil diksusi kelompok }\end{array}$ & 2,9 & 3,3 & 3,1 \\
\hline 10 & $\begin{array}{l}\text { Siswa menunjukan antusiasme / minat } \\
\text { terhadap kegiatan pembelajaran dengan } \\
\text { mengajukan pertanyaan atau umpan balik } \\
\text { kepada guru }\end{array}$ & 3,2 & 3,4 & 3,3 \\
\hline \multicolumn{2}{|c|}{ Rata-rata aktivitas siswa } & $3, \mathbf{1}$ & 3,4 & 3,25 \\
\hline \multicolumn{2}{|c|}{ Kategori } & & & Baik \\
\hline
\end{tabular}

Sub: Data Diolah (2018)

Gambaran rata-rata aktivitas belajar siswa dengan menerapkan model pembelajaran generatif pada siklus II

untuk setiap satuan aktivitas belajar yang dinilai dapat dilihat pada Gambar 7 berikut: 


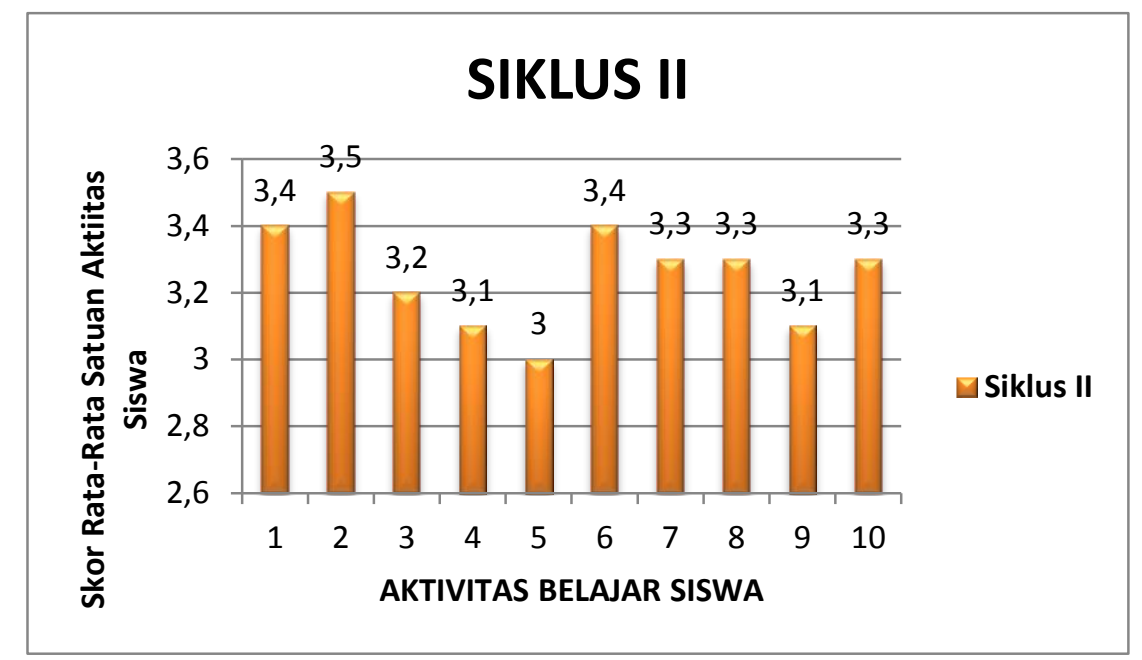

Gambar 7.Grafik Skor Rata-rata Satuan Aktivitas Belajar Siswa Siklus II

Untuk mendapatkan gambaran rata-rata aktivitas belajar siswa selama pembelajaran pada siklus IIpada pertemuan I dan II dapat dilihat pada Gambar 8 berikut:

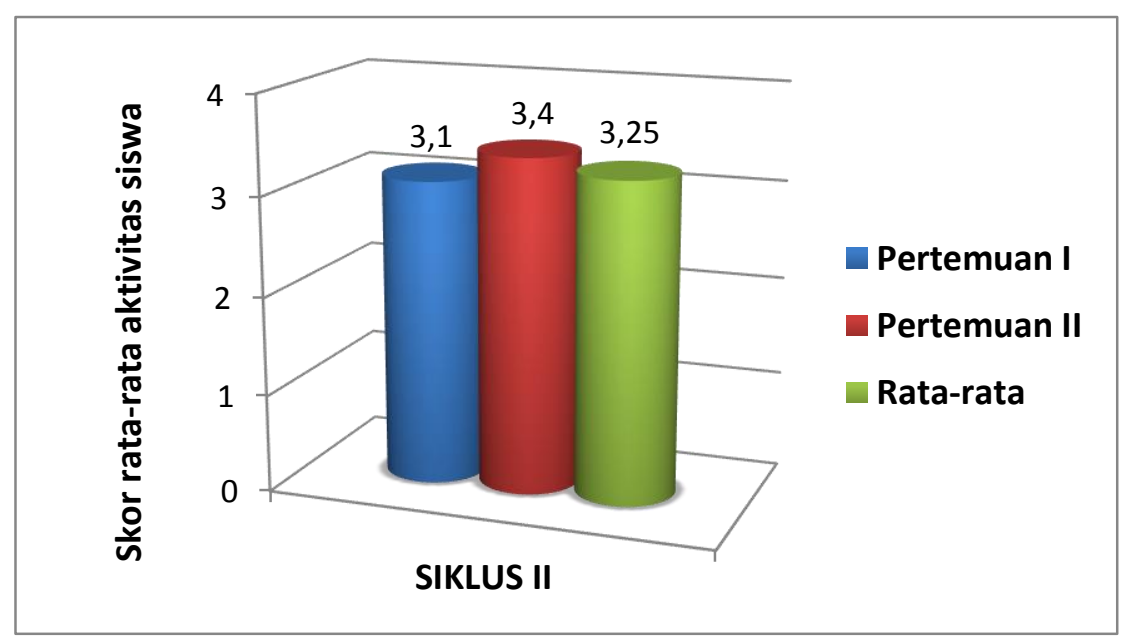

Gambar 8. Grafik Skor Rata-rata Aktivitas Belajar Siswa Siklus II

\section{Data Aktivitas Guru Siklus II}

Gambaran aktivitas guru dalam mengelola pembelajaran dengan menggunakan model guru pada Siklus II dapat dilihat pada tabel 7 Pembelajaran generatif diperoleh dengan berikut menggunakan lembar observasi aktivitas

Tabel 6. Skor Rata-rata Aktivitas Guru Siklus II

\begin{tabular}{cccccc}
\hline & & \multicolumn{3}{c}{ Skor/Siklus II } \\
\cline { 4 - 5 } No & \multicolumn{1}{c}{ Aspek Yang Dinilai } & Pert. I & Pert. II & Rata-Rata \\
\hline 1 & $\begin{array}{c}\text { A. Kegiatan Pendahuluan } \\
\text { 1. } \quad \begin{array}{l}\text { Guru membuka pelajaran dan } \\
\text { memeriksa kesiapan siswa }\end{array}\end{array}$ & 4 & 4 & 4 \\
& $2 . \quad \begin{array}{l}\text { Guru menyampaikan indikator dan } \\
\text { tujuan pembelajaran }\end{array}$ & 4 & 4 & 4 \\
\cline { 2 - 5 } & & & & \\
\hline
\end{tabular}




\begin{tabular}{|c|c|c|c|c|c|}
\hline & 3. & $\begin{array}{l}\text { Guru menyampaikan mengenai } \\
\text { model pembelajaran yang akan } \\
\text { dgunakan }\end{array}$ & 4 & 4 & 4 \\
\hline & 4. & $\begin{array}{l}\text { Guru memberikan apersepsi } \\
\text { tentang materi yang akan dipelajari }\end{array}$ & 4 & 4 & 4 \\
\hline \multirow[t]{9}{*}{2} & $\begin{array}{l}\text { B. Keg } \\
5 .\end{array}$ & $\begin{array}{l}\text { latan Inti } \\
\text { Guru menyajikan materi pelajaran } \\
\text { disertai dengan pertanyaan- } \\
\text { pertanyaan untuk mengkontruksi } \\
\text { pengetahuan atau konsep awal } \\
\text { siswa }\end{array}$ & 3 & 4 & 3,5 \\
\hline & 6. & $\begin{array}{l}\text { Guru meminta siswa untuk } \\
\text { mengemukakan ideatau gagasan } \\
\text { terkait dengan materi yang akan } \\
\text { dipelajari }\end{array}$ & 3 & 4 & 3,5 \\
\hline & 7. & $\begin{array}{l}\text { Guru mengelompokan } r \text { siswa } \\
\text { menjadi } 4 \text { kelompok atau } \\
\text { dikondisikan dengan cara meminta } \\
\text { siswa menghitung } 1,2,3 \text {, siswa } \\
\text { yang menyebutkan angka } 1 \text { masuk } \\
\text { dalam kelompok } 1 \text { dan begitu } \\
\text { seterusnya }\end{array}$ & 4 & 4 & 4 \\
\hline & 8. & $\begin{array}{l}\text { Guru memberikan Lebar Keja } \\
\text { Siswa (LKS) kepada masing- } \\
\text { masing kelompok dan menjelaskan } \\
\text { secara singkat tentang LKS yang } \\
\text { telah dibagikan }\end{array}$ & 3 & 4 & 3,5 \\
\hline & 9. & $\begin{array}{l}\text { Guru membantu siswa dan } \\
\text { mengorganisasikan siswa untuk } \\
\text { belajar dan berdiskusi untuk } \\
\text { menjawab soal yang terdapat pada } \\
\text { LKS }\end{array}$ & 3 & 3 & 3 \\
\hline & 10. & $\begin{array}{l}\text { Guru membimbing tiap-tiap } \\
\text { kelompok dalam menyelesaikan } \\
\text { soal yang ada }\end{array}$ & 3 & 4 & 3,5 \\
\hline & 11. & $\begin{array}{l}\text { Guru memberikan kesempatan } \\
\text { kepada setiap perwakilan } \\
\text { kelompok untuk mempresentasikan } \\
\text { hasil kerja kelompoknya }\end{array}$ & 4 & 4 & 4 \\
\hline & 12. & \begin{tabular}{lrr} 
Guru memberikan & \multicolumn{2}{c}{ kesempatan } \\
kepada kelompok & lain untuk \\
menanggapi & & hasil \\
kerja kelompok yang & mempresent \\
asikan hasil kerjanya & \multicolumn{2}{c}{}
\end{tabular} & 3 & 4 & 3,5 \\
\hline & 13. & Guru memberikan & 3 & 3 & 3 \\
\hline
\end{tabular}




\begin{tabular}{|c|c|c|c|c|}
\hline & $\begin{array}{l}\text { mengenai materi yang telah } \\
\text { dipelajari }\end{array}$ & & & \\
\hline & $\begin{array}{l}\text { 14. Guru memberikan reward berupa } \\
\text { pujian kepada kelompok tanpa } \\
\text { memperhatikan benar benar atau } \\
\text { salahnya konssep yang } \\
\text { dikemukakan siswa }\end{array}$ & 4 & 4 & 4 \\
\hline & $\begin{array}{l}\text { 15. Memberikan kesempatan kepada } \\
\text { siswa untuk bertanya mengenai } \\
\text { materi yang kurang dimengerti }\end{array}$ & 3 & 4 & 3,5 \\
\hline 3 & $\begin{array}{l}\text { C. Kegiatan Akhir } \\
\text { 16. Guru bersama sama menyimpulka } \\
\text { n materi yang telah dibahas }\end{array}$ & 3 & 3 & 3 \\
\hline & $\begin{array}{l}\text { 17. Guru memberikan PR terkait } \\
\text { dengan materi yang dipelajari }\end{array}$ & 4 & 4 & 4 \\
\hline & 18. Guru menutup proses pembelajaran & 4 & 4 & 4 \\
\hline Rat & rata aktivitas guru & 3,5 & 3,8 & 3,65 \\
\hline Kat & gori & & & Baik \\
\hline
\end{tabular}

Sub: Data Diolah (2018)

Gambaran rata-rata aktivitas guru dengan menerapkan model pembelajaran generatif pada siklus II untuk setiap satuan aktivitas yang dinilai dapat dilihat pada Gambar 9 berikut :

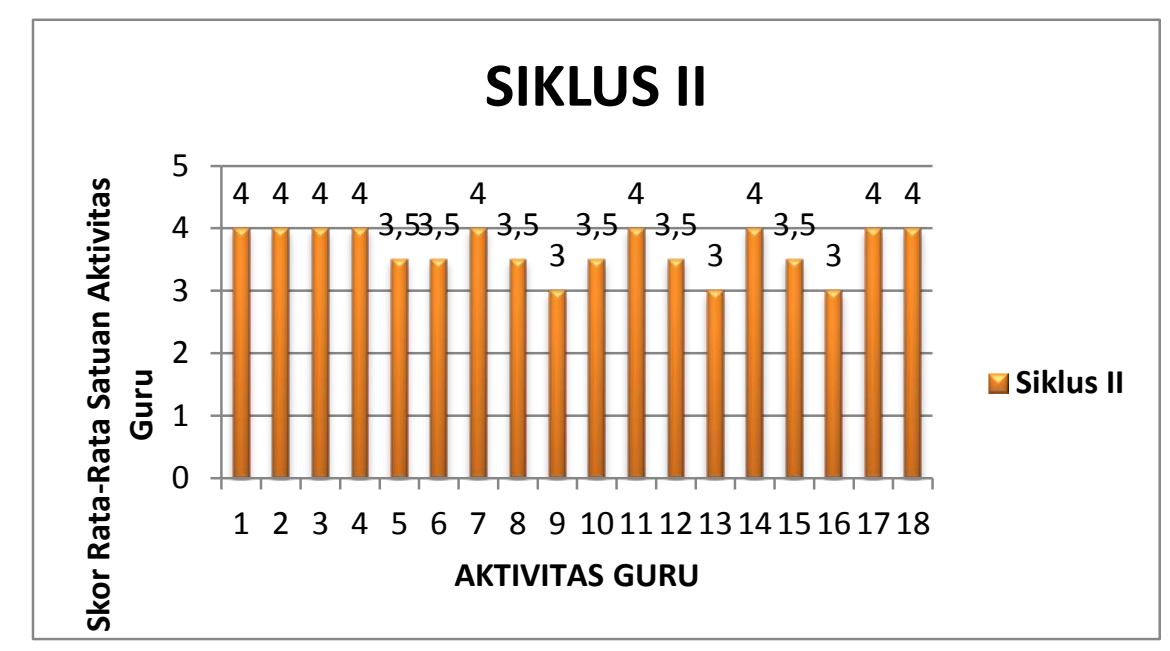

Gambar 4.9. Grafik Skor Rata-rata Satuan Aktivitas Guru Siklus II

Untuk mendapatkan gambaran rata-rata lihat pada gambar 10 berikut aktivitas guru selama pembelajaran pada siklus II pada pertemuan I dan II dapat di 


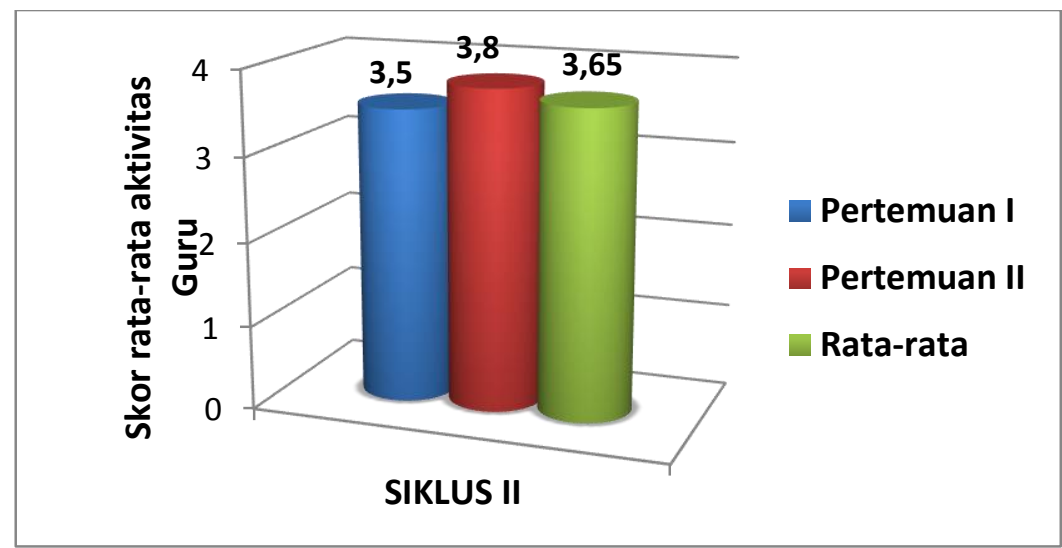

\section{Data Hasil Belajar Siswa Siklus II}

\section{Gambar 10. Grafik Skor Rata-rata Aktivitas Guru Siklus II}

Berdasarkan hasil analisis data hasil belajar siswa pada siklus II diperoleh hasil sebagaimana disajikan pada tabel 9 berikut :

Tabel 4.8. Data Analisis Ketuntasan Hasil Belajar Siswa Siklus II

\begin{tabular}{lccc}
\hline \multicolumn{1}{c}{ Skor } & Jumlah siswa & Presentase & Ketuntasan Belajar \\
\hline $0-69$ & 3 orang & $15 \%$ & Belum Tuntas \\
\hline $70-100$ & 17 orang & $85 \%$ & Sudah Tuntas \\
\hline Jumlah & $\mathbf{2 0}$ orang & $\mathbf{1 0 0 \%}$ & \\
\hline Keterangan $:$ & & & \\
\hline Tidak Tuntas & $\mathbf{: 3 ~ o r a n g}$ & \\
\hline Tuntas & $\mathbf{: 1 7}$ orang & \\
\hline Nilai Rata-rata & $\mathbf{: 8 1 , 5 0}$ & \\
\hline Nilai Maksimum & $\mathbf{: 9 5}$ & & \\
\hline Nilai Minimum & $\mathbf{: 6 5}$ & & \\
\hline Presentase Ketuntasan $: \mathbf{8 5 \%}$ &
\end{tabular}

Sub: Data Diolah (2018)

Untuk lebih jelasnya mengenai pembelajaran generatif pada siklus II dapat gambaran hasil belajar siswa kelas VII yang diajar dengan menggunakan model

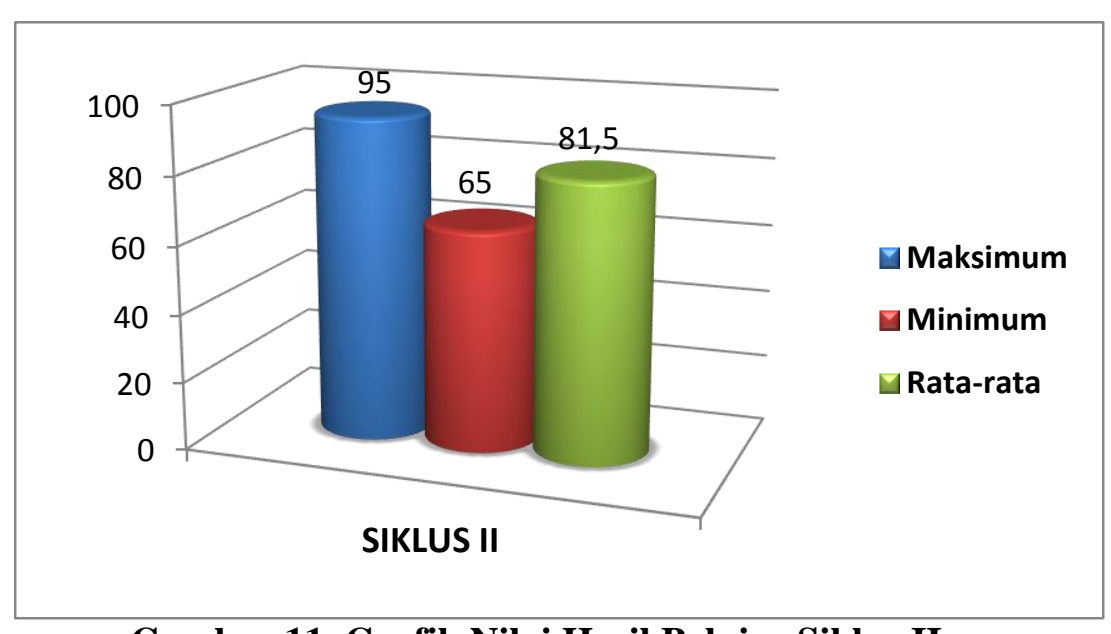

Gambar 11. Grafik Nilai Hasil Belajar Siklus II 
Selanjutnya berdasarkan analisis ketuntasan belajar siswa pada siklus II diperoleh hasil sebagaimana disajikan pada gambar 12 berikut

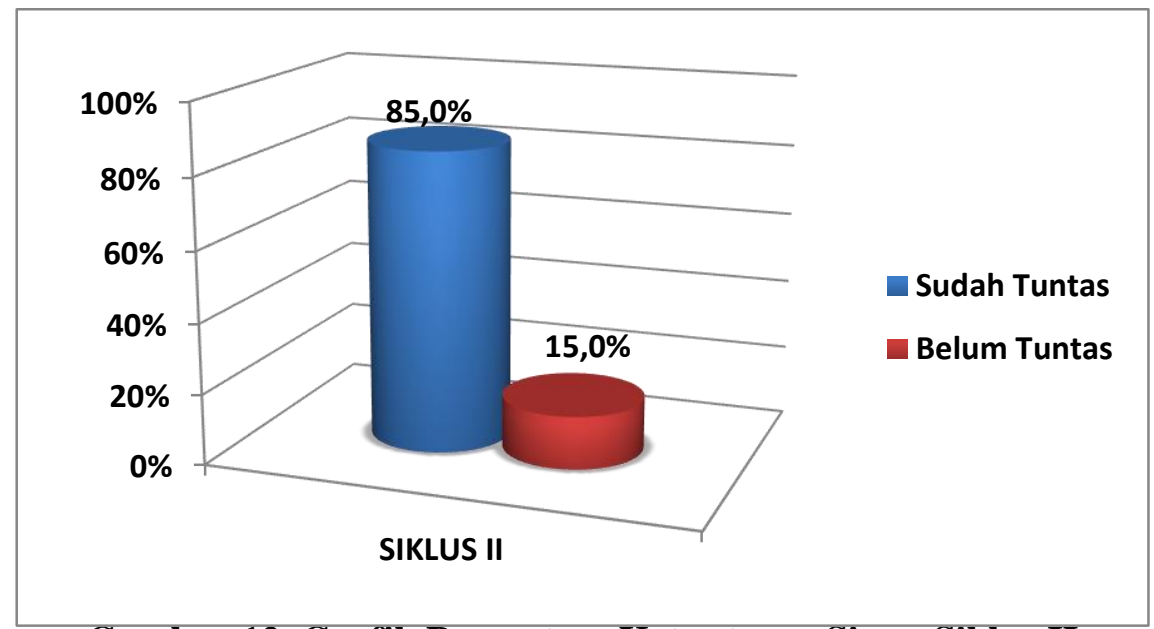

Gambar 12. Grafik Presentase Ketuntasan Siswa Siklus II

\section{Pembahasan Aktivitas Belajar Siswa selama belajar mengajar Berlangsung.}

Pada siklus I berdasarkan hasil analisis deskriptif terhadap aktivitas belajar siswa menunjukan skor rata-rata aktivitas belajar siswa pada siklus I sebesar 2,7 yang berkategori Cukup..

Berdasarkan hasil refleksi pada siklus I ditemukan ada beberapa aktivitas siswa yang masih belum terlaksana dengan baik. Oleh karena itu dilakukan perbaikan pada siklus selanjutnya.

Pada siklus II dari hasil analisis deskriptif terhadap skor rata-rata aktivitas belajar siswa pada siklus II menunjukkan adanya peningkatan yang signifikan dari aktivitas belajar siswa siklus I. dimana skor rata-rata aktivitas belajar siswa pada siklus II sebesar 3,25 dengan kategori Baik. Hal ini menunujukan bahwa penelitian telah berhasil karena telah memenuhi standar minimal aktivitas siswa yaitu 3,0.

\section{Aktivitas mengajar Guru}

Pada siklus I berdasarkan analisa deskriptif aktivitas Guru menunjukan skor rata-rata aktivitas guru sebesar 2,85 yang berkategori cukup. Berdasarkan hasil refleksi terhadap aktivitas guru, dengan mengetahui kekurangan-kekurangan pada siklus I, guru memperbaiki cara mengajarkan materi pembelajaran yang sesuai dengan Model Pembelajaran generatif, sehingga diharapkan pada pertemuan selanjutnya diperoleh peningkatan aktivitas guru pada siklus selanjutnya.

Pada siklus II aktivitas mengajar guru menunjukkan peningkatan yang signifikan, dimana pada siklus II skor ratarata aktivitas guru memperoleh nilai sebesar 3,65 yang berkategori baik. Hasil analisis dan pengamatan pada siklus II ini menunjukkan adanya peningkatan aktivitas guru dengan menerapkan Model Pembelajaran generatif. Hal ini menunujukan bahwa penelitian telah berhasil karena telah memenuhi standar minimal aktivitas mengajar guru yaitu 3,0.

\section{Hasil Belajar Siswa}

Pada siklus I Berdasarkan hasil tes hasil belajar siswa pada siklus I diperoleh nilai minimum sebesar 50; nilai maksimum 85; rata-rata hasil belajar siswa sebesar 72,25 . Secara klasikal dari 20 siswa yang mencapai persentase ketuntasan hasil belajar yaitu 13 siswa atau $65.00 \%$ yang mencapai nilai $\geq 70$ sesuai dengan nilai KKM Mata pelajaran 
IPS dan terdapat 7 orang siswa dengan presentase sebesar $35,00 \%$ siswa yang nilainya belum mencapai KKM yang ditentukan oleh sekolah yaitu 70. Presentase ketuntasan pada siklus I ini belum mencapai target peneliti yaitu mencapai ketuntasan belajar secara klasikal minimal $80 \%$.

Pada siklus II Berdasarkan hasil tes belajar siswa pada akhir siklus, terlihat bahwa hasil belajar siswa memperoleh nilai minimum 65 , nilai maksimum 95 , nilai ratarata hasil belajar siswa sebesar 81,50. Terdapat 17 siswa yang memperoleh nilai $\geq$ 70 atau ketuntasan hasil belajar secara klasikal sebesar $85 \%$ sedangkan jumlah siswa yang hasil belajarnya di bawah KKM atau yang memperoleh nilai $<70$ sebanyak 3 orang atau $15,00 \%$ yang belum tuntas. Dari hasil tersebut, menunjukkan peningkatan hasil belajar yang signifikan dari siklus I ke siklus II, Meskipun masih ada 3 siswa yang belum mencapai ketuntasan belajar.

Pada siklus II target ketuntasan hasil belajar siswa telah tercapai yaitu $85 \%$ siswa telah tuntas dalam hasil belajarnya. Dengan hal ini penelitian dianggap telah berhasil mencapai targetnya. Dalam penelitian ini keberhasilan siswa dalam tes hasil belajar siklus II memberikan gambaran bahwa penerapan model Pembelajaran generatif mampu meningkatkan hasil belajar siswa.

Dengan demikian, jawaban atas permasalahan penilitian telah ditemukan yaitu pembelajaran dengan Model Pembelajaran Generatif berhasil meningkatkan aktivitas belajar siswa dan juga dapat meningkatkan hasil belajar Mata pelajaran IPS siswa kelas $\mathrm{VII}_{2}$ SMP Negeri 2 Konawe khususnya pada materi Kondisi geografis dan penduduk.

\section{KESIMPULAN}

Berdasarkan hasil dalam penelitian ini dapat ditarik beberapa kesimpulan sebagai berikut: 1) Gambaran aktivitas belajar siswa Kelas $\mathrm{VII}_{2}$ SMP Negeri 2 Konawe yang di ajarkan dengan model generatif pada setiap siklus cenderung meningkat. Hal ini ditunjukkan dengan skor rata-rata pada setiap siklus, dimana pada siklus I skor rata-rata aktivitas siswa adalah 2,7 yang termasuk kategori cukup, dan meningkat pada siklus II menjadi 3,25 yang berkategori baik, 20 Gambaran aktivitas mengajar guru di Kelas $\mathrm{VII}_{2}$ SMP Negeri 2 Konawe yang di ajar dengan model pembelajaran Generatif pada setiap siklus cenderung meningkat. Hal ini ditunjukkan dengan skor rata-rata pada setiap siklus, dimana pada siklus I skor rata-rata aktivitas guru adalah 2,85 yang termasuk kategori cukup dan meningkat pada siklus II menjadi 3,65 yang berkategori baik, 3) Ada peningkatan hasil belajar IPS siswa Kelas $\mathrm{VII}_{2}$ SMP Negeri 2 Konawe yang diajar dengan model pembelajaran. Dimana terdapat peningkatan sebesar $17, \%$ yang diperoleh dari hasil selisih antara persentase kentuntasan siklus II dan siklus I. Dapat dilihat Pada siklus I, dengan nilai rata-rata hasil belajar 72,25 dengan persentase ketuntasan sebesar $65.00 \%$ yang mencapai KKM atau dari 20 siswa hanya 13 siswa yang memperoleh nilai $\geq 70$. Pada siklus II, diperoleh nilai rata-rata hasil belajar 81,50 dengan persentase ketuntasan sebesar $85 \%$ atau dari 20 orang siswa terdapat 17 orang siswa yang yang memperoleh nilai $\geq 70$ sesuai KKM yang ditetapkan sekolah. siswa yang yang memperoleh nilai $\geq 70$

\section{SARAN}

Berdasarkan kesimpulan di atas, maka peneliti Mengemukakan beberapa saran berikut: 1 ) Kepada para guru, khususnya SMP Negeri 2 Konawe di sarankan untuk mencoba menggunakan model pembelajaran Generatif pada setiap proses pembelajaran baik materi IPS maupun materi lainnya, 2) Bagi peneliti selanjutnya, terus mencari informasi dan mempelajari model pembelajaran Generatif sebelum 
melakukan Penelitian Tindakan Kelas (PTK) khususnya pada tahap-tahap model pembelajaran Generatif, sehingga diharapkan hasil yang diperoleh lebih baik dari penelitian sebelumnya.

\section{DAFTAR PUSTAKA}

Fathurrohman, P., 2007. Strategi Belajar Mengajar Melalui Penanaman Konsep Umum dan Konsep Islam. Refika Aditama. Bandung.

Febrian, W, K., 2012. Implementasi Model Pembelajaran Kooperatif Tipe Think Pair Share Untuk Meningkatkan Aktivitas Belajar Akuntasi Siswa Kelas XI IPS 1 SMA Negeri 2 Wonosari Tahun Ajaran 2011/2012. Jurnal Pendidikan Akuntasi Indonesia, Vol. X, No. 2, Tahun 2012 ISSN: 2354-6441. Diakses Tanggal 2 April 2015.

Grabowski, 2001. Taktik Mengembangkan Kemampuan Individual Siswa. Jakarta, GP Press

Hamalik, Oemar.2008. Proses Belajar Mengajar. Jakarta: Sinar Grafita.

Iskandar, 2012. Penelitian tindakan kelas. Jakarta: Referensi.

Syah, M.2008.Psikologi Pendidikan Dalam Pendekatan Baru. Jakarta: Rineka Cipta.

W.S. Winkel. 2004. Psikologi Pengajaran. Yogyakarta: Media Abadi 